\title{
Peran Perguruan Tinggi Lepisi dalam Memfasilitasi Pemberantasan Covid-19 di Karawaci Tangerang Banten
}

\author{
*Amir Hamzah1, RR Prima Dita Hapsari², Paula Theodora ${ }^{3}$, Dahlia Amelia ${ }^{4}$ \\ Dasa Raharjo Soesanto ${ }^{5}$, Ipah Masripah6 ${ }^{6}$, Hesti Umiyati ${ }^{7}$, Suhadarliyah ${ }^{8}$ \\ 1,3,4,6,7 Akademi Sekretari Dan Manajemen Lepisi, Tangerang, Banten, Indonesia \\ 2,5,8 STIE Bisma Lepisi, Tangerang, Banten, Indonesia
}

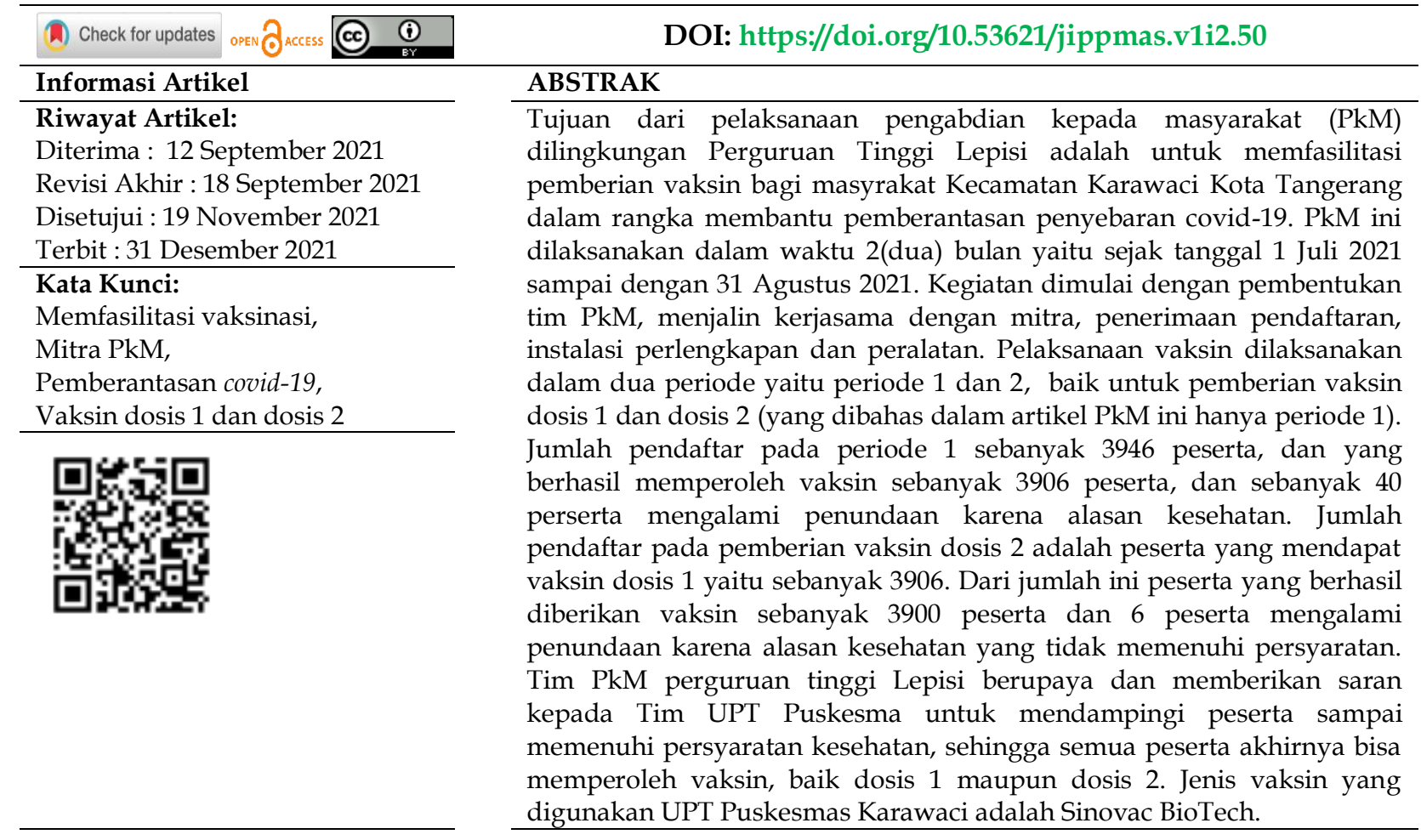

\section{PENDAHULUAN}

Perguruan Tinggi Lepisi merupakan lembaga yang bergerak di bidang pendidikan di bawah Yayasan Widya Anindya, yang terdiri dari STIE (Sekolah Tinggi Ilmu Ekonomi) Bisma Lepisi dan ASM (Akademi Sekretari dan Manajemen) Lepisi, yang berada di wilayah Kecamatan Karawaci, Kota Tangerang, Provinsi Banten.

Hingga 17 Agustus 2021 jumlah data terkonfirmasi Covid 19 di Kota Tangerang sebesar 27.890, angka ini 26,7\% dari angka konfirmasi keseluruhan Provinsi Banten (www.bantenprov.go.id, 2021). Dari data tersebut 25.670 sudah dinyatakan sembuh dan 412 dinyatakan meninggal. Angka ini cukup besar, mengingat posisi Kota Tangerang termasuk wilayah penyangga ibukota negara, sehingga mobilitas masyarakat yang melintasi wilayah ini cukup masif. Dengan kondisi ini menyebabkan masyarakat Kota Tangerang cukup rentan terkait penularan Covid 19.

Lebih jauh lagi, angka terkonfirmasi tersebut juga masih cukup tinggi di wilayah Tangerang, sebagaimana disebutkan Wali Kota Tangerang "masih adanya sejumlah perkembangan kasus covid-19 positif selama PPKM Level 4 mulai tanggal 24 Juli 2021 hingga tanggal 2 Agustus 2021" (Kurniawan, 2021). “Data terkorfirmasi khusus untuk Kecamatan Karawaci per tanggal 3 Agustus 2021" (www.bantenprov.go.id, 2021) tampak sebagai berikut: 
Peran Perguruan Tinggi Lepisi dalam Memfasilitasi Pemberantasan Covid-19 di Karawaci Tangerang Banten

Tabel 1. Data Konfirmasi Kecamatan Karawaci

\begin{tabular}{|c|c|c|c|c|c|}
\hline \multirow[b]{2}{*}{ KECAMATAN } & \multicolumn{5}{|c|}{ DATA KONFIRMASI } \\
\hline & $\begin{array}{c}\text { SUSPEK } \\
\text { AKTIF } \\
\text { DIRAWAT }\end{array}$ & $\begin{array}{c}\text { KONFIRMASI } \\
\text { TOTAL }\end{array}$ & $\begin{array}{c}\text { KONFIRMASI } \\
\text { DIRAWAT }\end{array}$ & $\begin{array}{l}\text { KONFIRMASI } \\
\text { SEMBUH }\end{array}$ & $\begin{array}{l}\text { KONFIRMASI } \\
\text { MENINGGAL }\end{array}$ \\
\hline KARAWACI & 6 & 78 & 7 & 70 & 1 \\
\hline $\begin{array}{l}\text { PABUARAN } \\
\text { TUMPENG }\end{array}$ & 5 & 271 & 15 & 250 & 6 \\
\hline BOJONG JAYA & 5 & 112 & 6 & 103 & 3 \\
\hline PABUARAN & 7 & 143 & 6 & 132 & 5 \\
\hline NAMBO JAYA & 2 & 170 & 5 & 161 & 4 \\
\hline NUSA JAYA & 8 & 250 & 11 & 237 & 2 \\
\hline $\begin{array}{l}\text { SUMUR } \\
\text { PACING }\end{array}$ & 1 & 111 & 3 & 108 & 0 \\
\hline CIMONE JAYA & 21 & 265 & 12 & 245 & 8 \\
\hline SUKAJADI & 3 & 172 & 18 & 149 & 5 \\
\hline KOANG JAYA & 2 & 128 & 6 & 121 & 1 \\
\hline PASAR BARU & 6 & 110 & 10 & 99 & 1 \\
\hline BUGEL & 9 & 245 & 8 & 231 & 6 \\
\hline $\begin{array}{l}\text { KARAWACI } \\
\text { BARU }\end{array}$ & 30 & 383 & 8 & 369 & 6 \\
\hline CIMONE & 19 & 317 & 17 & 293 & 7 \\
\hline GERENDENG & 7 & 298 & 19 & 276 & 3 \\
\hline MARGASARI & 8 & 176 & 9 & 159 & 8 \\
\hline TOTAL & 139 & 3229 & 160 & 3003 & 66 \\
\hline
\end{tabular}

Data konfirmasi total di Kecamatan Karawaci mencapai 3. 229 kasus. Salah satu penyebab tingginya angka penularan covid-19 yakni tingkat kesadaran mereka yang sangat kurang, pengetahuan tentang virus serta cara pencegahannya juga sangat rendah (Amir \& dkk., 2021). Untuk mencegah terjadinya penyebarluasan penularan covid-19 maka dilakukan berbagai upaya pencegahan, baik oleh pemerintah, tenaga kesehatan, maupun lapisan masyarakat. Dalam rangka menghadapai new normal langkah gencar yang dilakukan adalah "penerapan protokol kesehatan 3M (menggunakan masker, mencuci tangan, dan menjaga jarak) yang merupakan tindakan pencegahan non pharmacologial treatment". (Syamsir \& dkk., 2021)

Selain tindakan pencegahan tersebut, pemerintah Indonesia sedang berusaha mengembangkan vaksin covid-19 dan merencanakan dan merencanakan immunisasi untuk seluruh warga negara Indonesia. "Vaksin tidak hanya melindungi individu, namun juga akan memberikan perlindungan bagi orang yang tidak dapat diimunisasi, karena penyakit tertentu. Vaksin tidak menimbulkan penyakit. Vaksin yang dipakai sudah dijamin keamanannya dan umumnya tidak menimbulkan reaksi simpang(efek samping) yang berat" (Iskak \& dkk., 2021).

Melihat kondisi ini, Perguruan Tinggi Lepisi menyadari untuk berperan serta dalam memberikan dukungan kepada pemerintah dan masyarakat untuk segera menekan angka kasus Covid 19. Salah satu bentuk dukungan nyata dari Perguruan Tinggi Lepisi, dengan menjembatani masyarakat demi mempermudah mendaftar dan memperoleh vaksin Covid 19. Hal ini disadari harus dilakukan, karena dengan semakin tingginya jumlah masyarakat yang telah divaksin, diharapkan akan segera menekan angka penyebaran virus ini (Sardjoko, 2021).

Selama ini pemerintah dalam mendistribusikan vaksin, hanya mengandalkan fasilitas Puskesmas ataupun gedung-gedung pemerintahan (Lubabah, 2021). Hal ini 
cukup menyulitkan masyarakat, karena di tengah antusiasme masyarakat yang sangat tinggi, masyarakat dan pemerintah juga harus mengikuti aturan protokol kesehatan yang membatasi jumlah masyarakat yang dapat berkumpul di satu kawasan dalam waktu yang sama. Perguruan Tinggi Lepisi melihat masyarakat sedikit mengalami kendala terkait sarana dan prasarana pendaftaran untuk memperoleh vaksin Covid 19, waktu tunggu penentuan pemberian vaksin, serta yang tak kalah penting adalah tempat pemberian vaksin. Kondisi ini mendorong Perguruan Tinggi Lepisi untuk hadir membantu pemerintah begitu pula masyarakat dengan memfasilitasi kebutuhan akan sarana dan prasarana pendukung terkait pemberian vaksin bagi masyarakat sekitar.

\section{PERMASALAHAN}

Permasalahan yang dihadapi tim pengabdian kepada masyarakat Perguruan Tinggi Lepisi dalam memfasilitasi pemberantasan virus corona covid-19 di wilayah Karawaci Tangerang adalah:

1. Menjalin kerja sama dengan UPT Puskemas Kecamatan Karawaci, petugas gugus covid-19, dan pemerintah setempat.

2. Memperoleh persetujuan pemakaian fasilitas kampus dalam kegiatan vaksinasi

3. Penyebaran informasi pelaksanaan vaksin di lingkungan Perguruan Tinggi Lepisi bagi warga Kecamatan Karawaci.

4. Pendaftaran warga yang ingin memperoleh vaksin

5. Penataan tempat pelaksanaan vaksinasi.

6. Pengawasan pelaksanaan vaksinasi yang memenuhi ketentuan protokol kesehatan.

\section{METODE PELAKSANAAN}

Cara atau Metode pelaksanaan kegiatan pengabdian kepada masyarakat dalam memfasilitasi pemberantasan covid-19 di Karawaci Tangerang adalah:

1. Perencanaan kegiatan

2. Menjalin kerja sama dengan mitra

3. Penetapan hari pelaksanaan

4. Penyebaran informasi

5. Pendaftaran calon peserta vaksin

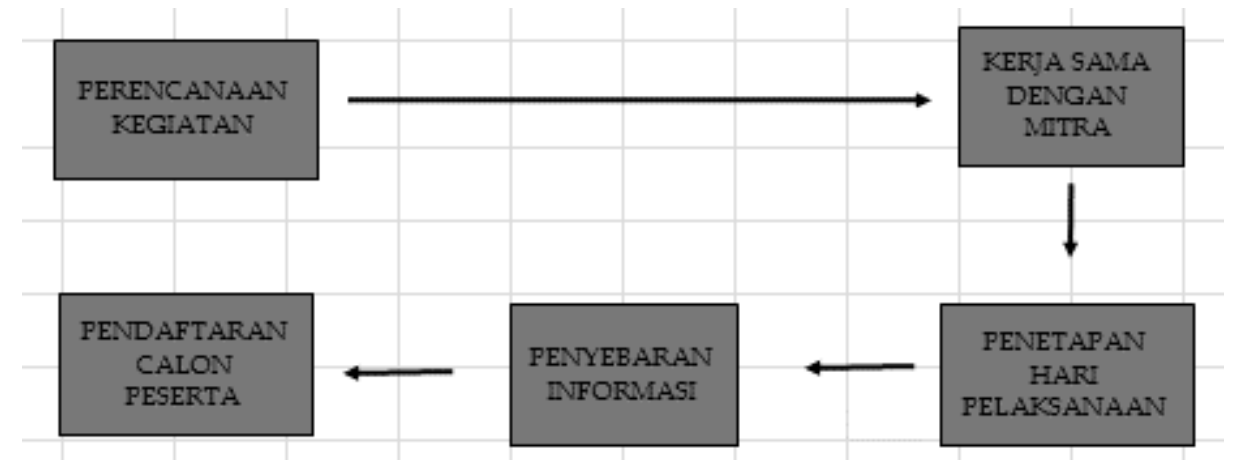

Gambar 1. Alur Pelaksanaan Kegiatan PkM

\section{Perencanaan kegiatan}

Pada tahap perencanaan ini, tim pengabdian kepada masyarakat menetapkan sasaran calon peserta vaksin, mitra kerja sama, cara penyebaran informasi, hari pelaksanaan, pendaftaran calon peserta vaksin, lokasi dan peralatan yang dibutuhkan (Iskak \& dkk., 
Peran Perguruan Tinggi Lepisi dalam Memfasilitasi Pemberantasan Covid-19 di Karawaci Tangerang Banten

2021). Dalam penetapan calon peserta, tim PKM mengadakan kunjungan dan pembicaraan dengan satuan tugas covid Kecamatan Karawaci dan kepala lingkungan yaitu kelurahan dan rukun tetangga guna memperoleh informasi tentang jumlah kelurahan yang ada di Kecamatan Karawaci Tangerang sebagai sasaran pemberian vaksin. Perencanaan tentang mitra kerja meliputi kerja sama dengan kelurahan yang ada di kecamatan Karawaci Tangerang, UPT Puskemas Kecamatan Karawaci Baru, dan Satuan Gusus Covid Kecamatan Karawaci. Rencana tentang penyebaran informasi pelaksanaan vaksin meliputi pemakaian media sosial seperti whats App dan pamplet di lingkungan Kecamatan Karawaci dengan bantuan kepala lingkungan yaitu kelurahan dan rukun warga. Penetapan hari pelaksanaan dapat ditentukan setelah memperoleh kesepakatan dengan mitra kerja yaitu UPT Puskesmas dan Satuan Gugus Covid.

Rencana tentang pendaftaran calon peserta menggunakan media google form yang dirancang tim PKM dan disebarkanluaskan melalui whats App yang dibuat oleh im PKM dan kepala lingkungan. Selain melalui google form, pendaftaran juga dapat dilakukan secara manual disetiap wilayah kelurahan.

Rencana tengtang lokasi pelaksanaan vaksin yaitu kampus "Perguruan Tinggi Lepisi Jl. KS. Tubun No. 11 Pasar Baru Karawaci Tangerang". Fasilitas kampus yang digunakan untuk pelaksanaan pemberian vaksin meliputi area parkir sebagai tempat pengambilan nomor antri, pemeriksaan kesehatan calon peserta, dan pendopo perguruan tinggi Lepisi sebagai tempat pemberian vaksin dan area observasi setelah mendapat suntikan vaksin. Peralatan yang dibutuhkan meliputi meja, kursi, tenda, toa dan peralatan lain yang dibutuhkan untuk mendukung kelancaran kegiatan pemberian vaksin.

\section{Kerjasama dengan mitra}

Kerjasama ini dilakukan Peguruan Tinggi Lepisi dalam rangka kelancaran pemberian vaksin kepada anggota masyarakat di Kecamatan Karawaci Tangerang sebagai bukti nyata pelaksanaan tridharma perguruan tinggi di tengah masyarakat. Dukungan dari mitra atas kehadiran Perguruan Tinggi Lepisi dalam memfasilitasi pelaksanaan pemberian vaksin kepada masyarakat di Kecamatan Karawaci sangat menggembirakan terutama dari pihak UPT Puskesmas, kepala lingkungan, babinsa, dan satuan gugus covid Kecamatan Karawaci, sehingga diperoleh kesepakatan untuk melaksanakan pemberian vaksin di Perguruan Tinggi Lepisi Tangerang.

\section{Penetapan hari pelaksanaan}

Tim PKM Perguruan Tinggi Lepisi dan mitra memperoleh kesepakatan tentang hari pelaksanaan pememberian vaksin bagi warga Kecamatan Karawaci yaitu dua periode pemberian vaksin dosis 1 dan pemberian vaksin dosis 2 yang akan dilaksanakan di Perguruan Tinggi Lepisi. Jadwal pelaksanaan kegiatan ini sebagai berikut:

Tabel 2. Jadwal kegiatan vaksin di Perguruan Tinggi Lepisi

\begin{tabular}{|c|c|c|c|c|c|}
\hline \multicolumn{3}{|c|}{ Agustus } & \multicolumn{3}{|c|}{ Agustus/September } \\
\hline Tanggal & Hari & Keterangan & Tanggal & Hari & Keterangan \\
\hline $02 / 8 / 21$ & Senin & Dosis 1 & $16 / 8 / 21$ & Senin & Dosis 2 \\
\hline $03 / 8 / 21$ & Selasa & & $18 / 8 / 21$ & Rabu & \\
\hline $04 / 8 / 21$ & Rabu & & $19 / 8 / 21$ & Kamis & \\
\hline
\end{tabular}


Peran Perguruan Tinggi Lepisi dalam Memfasilitasi Pemberantasan Covid-19 di Karawaci Tangerang Banten

\begin{tabular}{|c|c|c|c|c|c|}
\hline $05 / 8 / 21$ & Kamis & & $20 / 8 / 21$ & Jum'at & \\
\hline $09 / 8 / 21$ & Senin & Dosis 1 & $30 / 8 / 21$ & Senin & Dosis 2 \\
\hline $10 / 8 / 21$ & Selasa & & $31 / 8 / 21$ & Selasa & \\
\hline $11 / 8 / 21$ & Rabu & & $01 / 9 / 21$ & Rabu & \\
\hline $12 / / 8 / 21$ & Kamis & & $02 / 9 / 21$ & Kamis & \\
\hline
\end{tabular}

\section{Penyebaran informasi}

Setelah hari pelaksanaan ditetapkan oleh tim PkM bersama mitra, informasi pelaksanaan vaksin di perguruan tinggi Lepisi disebarluaskan dengan menggunakan surat pemberitahuan yang disampaikan kepada kepala lingkungan di Kecamatan Karawaci, dan diharapkan informasi ini akan sampai kepada warga sehingga dapat membantu mereka untuk memperoleh vaksin dengan lebih mudah, karena akan dilaksanakan dari jarak yang tidak terlalu jauh dari tempat tinggal warga Kecamatan Karawaci.

\section{Pendaftaran calon peserta vaksin}

Pendaftaran calon peserta vaksin dilakukan dengan dua cara yaitu mendaftar di lingkungan masing-masing secara manual, dan mendaftar melalui link google form yang disiapkan tim PkM perguruan tinggi Lepisi. Data yang harus terekam dalam pendaftaran calon peserta vaksin antara lain: nama lengkap, NIK, tempat/tanggal lahir, usia, jenis kelamin, alamat sesuai KTP, sudah atau belum pernah memperoleh vaksin dan tanggal pelaksanaan. Link google form ini di share ke whats App kepala lingkungan dan selanjutnya kepala lingkungan akan melakukan share link kepada warganya. Pendaftaran diharapkan sudah selelai seminggu sebelum hari pelaksanaan pemberian vaksin. Berikut ini contoh link google form pendaftaran vaksinasi di Perguruan Tinggi Lepisi.

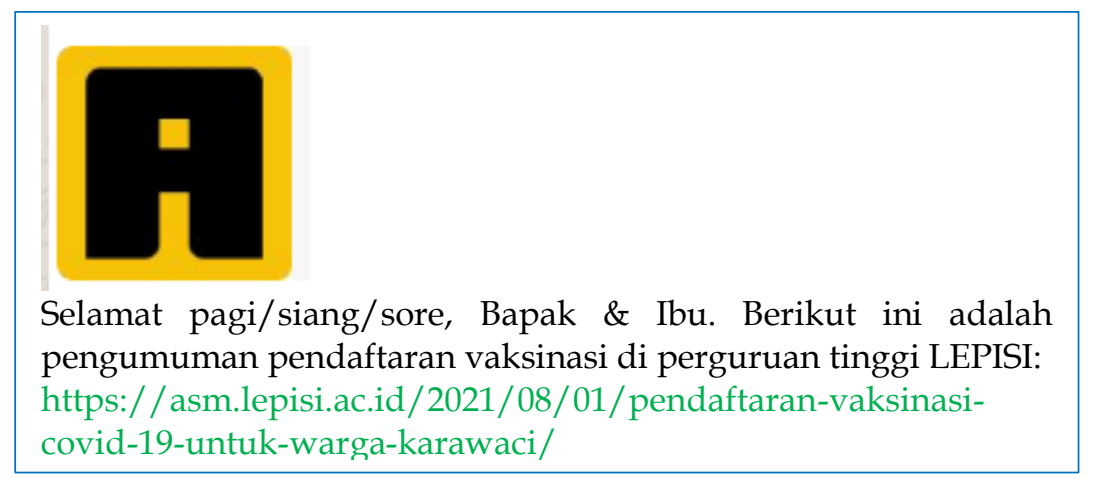

Gambar 2. Link Pendaftaran Vaksinasi

\section{PELAKSANAAN}

Pelaksanaan kegiatan vaksin di Perguruan Tinggi Lepisi dalam rangka PkM di wilayah Kecamatan Karawaci dibagi menjadi 2 (dua) periode yaitu periode 1 mulai tanggal 2 Agustus sampai tanggal 5 Agustus 2021 dan periode 2 dimulai tanggal 9 Agustus sampai dengan tanggal 12 Agustus 2021 (lihat tabel 2 di muka). Artikel PkM ini hanya membahas pelaksanaan vaksin periode 1 (satu). 


\section{Pendaftaran}

Penerimaan pendaftaran vaksin dimulai sejak H-15 yaitu tanggal 17 Juli 2021 sampai dengan tanggal 31 Juli 2021. Pendaftaran calon peserta vaksin dilakukan dengan dua cara yaitu calon peserta mengisi formulir pendaftaran yang disediakan di kelurahan dan pendaftaran melalui link google form. Anggota tim PkM melakukan rekapitulasi data pendaftar baik secara manual maupun pendaftaran melalui link. Rekapitulasi data calon peserta vaksin ini diserahkan ke UPT Puskesmas Karawaci pada H-5 yang berguna untuk mempersiapkan jumlah dan perlengkapan vaksin yang dibutuhkan. Berikut ini gambar anggota tim PKM sedang melakukan rekapitulasi data calon peserta vaksin pada h-7 untuk periode 1 :
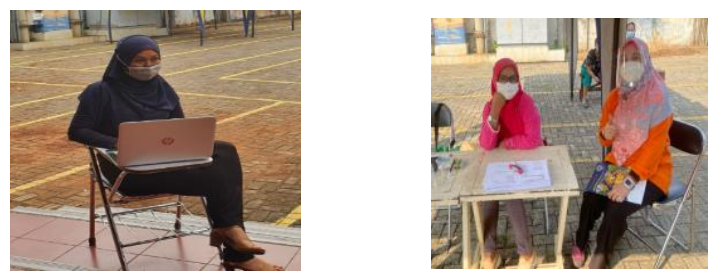

Gambar 3. Anggota tim PKM merekapitulasi data pendaftar(online kiri dan manual kanan)

Hasil rekapitulasi pendaftar vaksin dosis 1 untuk pemberian vaksin tanggal 2 Agustus sampai tanggal 5 Agustus 2021 adalah sebagai berikut:

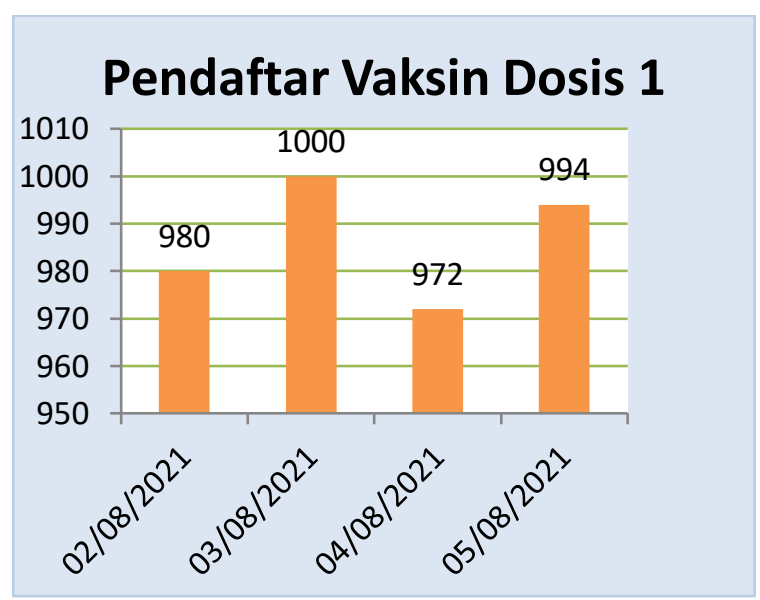

Gambar 4. Grafik jumlah pendaftar periode 1

Data pada pendaftar vaksin dosis 1 di atas terdiri dari 980 calon peserta untuk pelaksanaan tanggal 2 Agustus 2021. Data pendaftar pada 3 Agustus 2021 sebanyak 1.000 calon peserta. Pada tanggal 4 Agustus 2021 jumlah calon peserta sebanyak 972 dan pada tanggal 5 Agustus 2021 calon peserta yang telah mendaftar sebanyak 994. Jumlah keseluruhan calon peserta pada periode 1 untuk dosis 1 sebanyak 3.946 orang.

\section{Instalasi peralatan dan perlengkapan}

Instalasi peralatan dan perlengkapan dikerjakan sejak $\mathrm{H}-2$ sehingga pada hari $\mathrm{H}$ di lapangan parkir dan pendopo, seperti gambar berikut ini. 

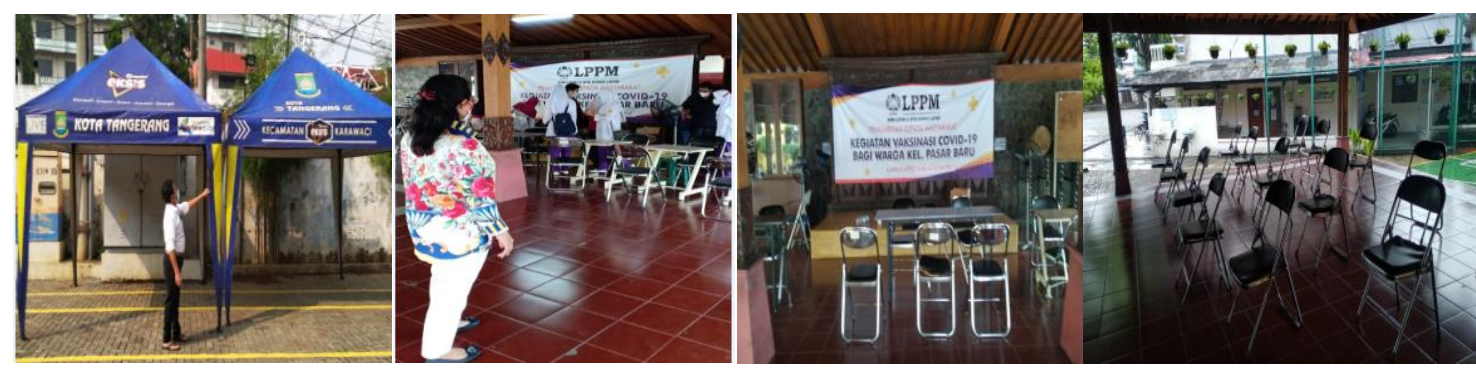

Gambar 5. Instalasi peralatan dan perlengkapan pelaksanaan vaksinasi( dari kiri: tempat pengambilan nomor antri, tempat pemeriksaan kesehatan, tempat pemberian vaksin, dan tempat observasi).

Instalasi peralatan dan perlengkapan vaksin diselesaikan dalam 2(dua) hari kerja. Tempat pengambilan nomor antri (gambar sebelah kiri) dilengkapi dengan tenda yang merupakan kontribusi dari pemerintah Kecamatan Karawaci sebanyak 2(dua) tenda dengan kapasitas 2 (dua) meja dan 6 (enam) kursi. Tempat pemeriksaan kesehatan (gambar kedua dari kiri) dirancang sebanyak 4 (empat) unit meja dengan jumlah kursi sebanyak 8(delapan) unit yang merupakan kontribusi dari Perguruan Tinggi Lepisi. Tempat pemeriksaan kesehatan ini juga dilengkapi dengan peralatan aliran listrik dan toa.

Tempat pemberian vaksin (gambar ketiga dari kiri) dirancang di dalam Pendopo perguruan tinggi Lepisi sebanyak 8 (delapan) meja, masing-masing dilengkapi dengan kursi untuk tim UPT Puskesmas dan kursi untuk peserta vaksin. Tempat pemberian vaksin ini juga dilengkapi dengan peralatan aliran listrik dan toa untuk kelancaran pemberian vaksin. Peralatan dan penglengkapan yang digunakan pada tempat pemberian vaksin merupakan kontribusi dari Perguruan Tinggi Lepisi. Selanjutnya dirancang juga tempat bagi peserta vaksin yang sudah mendapatkan dosis untuk observasi setelah pemberian vaksin sebanyak 40 puluh unit kursi. Tempat observasi ini juga dirancang di dalam Pendopo Perguruan Tinggi Lepisi.

\section{Alur pelaksanaan pemberian vaksin dosis 1 dan dosis 2}

Alur pelaksanaan kegiatan vaksin dimulai dari pengambilan nomor antri, pemeriksaan atau validasi data calon peserta, pemerikasaan kesehatan atau tekanan darah menggunakan kartu kendali, pemberian vaksin, observasi setelah pemberian vaksin, dan pengambilan bukti vaksin (Zubaedah, 2021). Alur pelaksanaan vaksin ini digambarkan sebagai berikut:

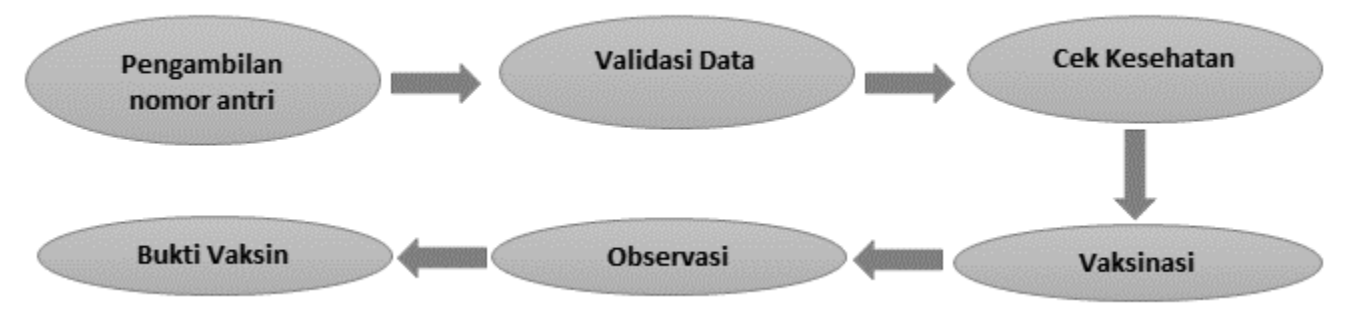

Gambar 6. Alur pelaksanaan vaksinasi Perguruan Tinggi Lepisi

Keterangan:

1. Pengambilan nomor antri dan validasi data. 
Peserta pada hari yang ditentukan menghadiri tempat pelaksanaan vaksin pada waktu yang telah ditentukan untuk mengambil nomor antri dan formulir atau kartu kendali. Peserta yang mendapat nomor antri dan kartu kendali hanya calon peserta yang membawa identitas seperti KTP atau KK. Jika data sudah sesuai peserta dipersilahkan menuju meja pemeriksaan kesehatan.

2. Cek Kesehatan

Petugas melakukan pemeriksaan kondisi kesehatan calon peserta penerima vaksin seperti tekanan darah (mengukur tekanan darah) dan riwayat penyakit(melalui wawancara). Jika dinyatakan layak vaksin, peserta melanjutkan ke meja pemberian vaksin.

3. Vaksinasi

Petugas memberikan vaksin dosis pertama sesuai dengan prinsip penyuntikan aman.

4. Observasi

Setelah dilakukan vaksin, dilakukan observasi selama 30 menit untuk memonitor reaksi dari vaksin apakah terjadi KIPI (Kejadian Ikutan Pasca Imunisasi). Ada keluhan atau tidak ada keluhan, setelah dilihat peserta dalam keadaan baik, peserta melanjutkan ke meja pencatatan.

5. Pencatatan

Petugas mencatat dan memberikan kartu vaksin dosis pertama kepada peserta vaksin.

Pelaksanaan vaksinasi bagi masyarakat Kecamatan Karawaci pada tanggal 2, 3, 4 dan 5 Agustus 2021 berlangsung dengan lancar dan aman. Tim PkM juga aktif dalam mendukung pelaksanaan vaksinasi di lingkungan Pergururan Tinggi Lepisi. Berikut dokumentasi tim PkM pada hari pelaksanaan vaksinasi.

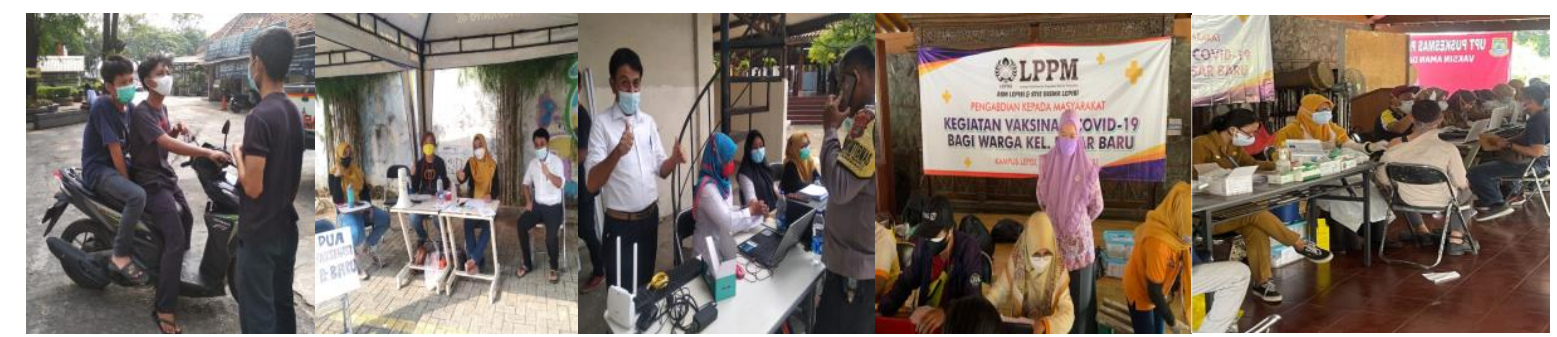

Gambar 7. Kegiatan Tim PkM(dari kiri, pemeriksaan suhu tubuh, pengambilan nomor antri, pemeriksaan kesehatan, dan pemberian vaksin)

\section{HASIL DAN DISKUSI}

Kegiatan pengabdian kepada masyarakat dalam bentuk pemberian vaksinasi juga dilaksanaka oleh Lamirin \& dkk. (2021). Kegiatan Vaksin Tahap Pertama yang berlangsung pada hari Kamis, 15 April 2021, pukul 08.30 WIB s/d 13.00 WIB, di aula perguruan buddhis bodhicitta Medan. Sebanyak 435. Peserta tampak antusias mengikuti kegiatan vaksinasi tersebut. Tim pengabdian masyarakat merujuk pada Surat Edaran Ditjen P2P bertanggal 18 Februari 2021, setidaknya ada 14 pertanyaan yang harus bisadijawab calon penerima vaksin di meja penyaringan.Petunjuk teknis vaksinasi covid-19 menyatakan bahwa setiap pos vaksinasi setidaknya memiliki satu rangkaian proses dengan empat meja.Persiapan 
sebelum suntik vaksin Covid-19 adalah melakukan pendaftaran ulang di meja No.1 adalah registrasi atau verifikasi pendaftaran, Para calon penerima vaksin Covid-19 menerima formulir lembar pertanyaan-pertanyaan yang merupakan bagian skrining atau penyaringan peserta vaksinasi. Meja 2 adalah penyaringan dengan anamnesa dan pemeriksaan Kesehatan oleh perawat yang membantu proses skrining atau penyaringan peserta vaksinasi.Meja 3 adalah tempat dilakukannya vaksinasi. Meja 4 adalah meja registrasi setelah penyuntikan yang disertai adanya ruang tunggu untuk dilakukannya masa observasi minimal 30 menit.Kegiatan vaksinasi Covid-19 tahap kedua dilaksanakan pada selasa, 18Mei 2021 mulai pukul 08.30 di Aula Perguruan Buddhis Bodhicitta Medan. Kegiatan vaksinasi berlangsung sesuai dengan protokol Kesehatan seperti halnya kegiatan vaksinasi tahap pertama. Setelah dilakukan penyuntikan vaksin COVID-19, peserta vaksin dihimbau agar tetap disiplin dalam menerapkan protokol kesehatan 4M (memakai masker, menjaga jarak, dan menghindari kerumunan, serta mencuci tangan). Serangkaian kegiatan vaksinasi yang sudah diikuti merupakan suatu bentuk upaya agar seluruh guru dan tenaga pendidik tetap sehat dan terhindar dari Covid-19 serta sdapat melakukan pempelajaran tatap muka kembali dengan aman. Tetap semangat dan sehat selalu untuk tenagapendidik dan kependidikan serta masyarakat sekitarnya.

\section{Pemberian Vaksin dosis 1}

Sesuai dengan "standar Badan Kesehatan Dunia atau WHO, setiap penduduk akan mengikuti dua kali penyuntikan atau membutuhkan dua dosis vaksin" (Mandong, 2019). Terdapat "7 (tujuh) jenis vaksin covid-19 yang dapat digunakan dalam proses vaksinasi di Indonesia. Ketujuh vaksin tersebut diproduksi oleh Bio farma, Astra Zaneca, Shinoparm, Moderna, Novavax Inc., Pfizer Inc. and BioNtech dan Sinovac Biotech" (Prayitno \& dkk., 2020). Pemberian vaksin covid-19 dalam PkM Perguruan Tinggi Lepisi adalah Sinovac Biotech.

Hasil pelaksaan vaksin periode 1 di lingkungan Perguruan Tinggi Lepisi disajikan dalam grafik berikut:

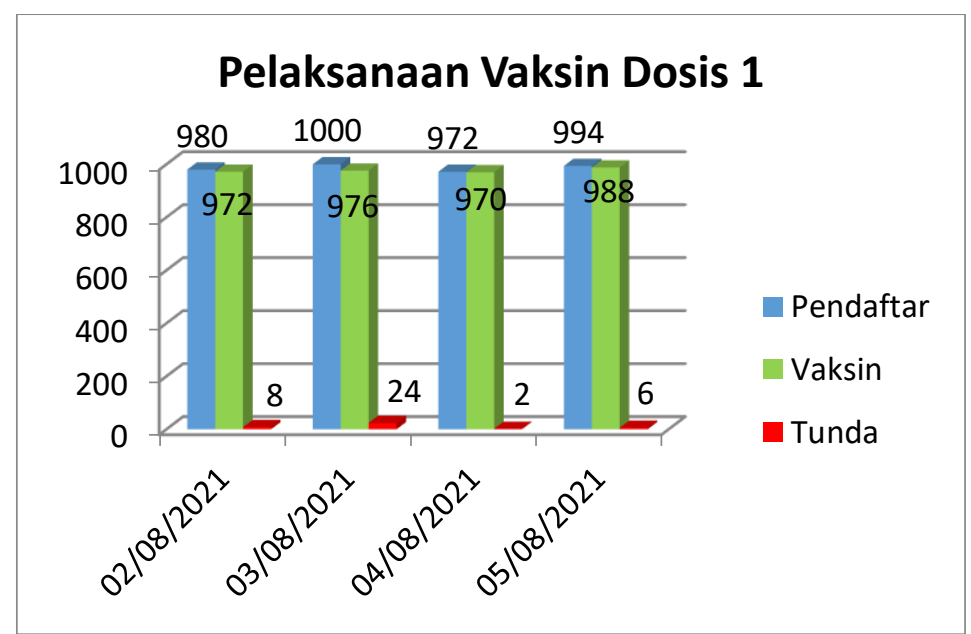

Gambar 8. Grafik hasil pelaksananaan vaksin dosis 1 
Peran Perguruan Tinggi Lepisi dalam Memfasilitasi Pemberantasan Covid-19 di Karawaci Tangerang Banten

Pelaksanaan vaksin dosis 1 yang dilakukan pada tanggal 2 Agustus 2021 menunjukkan jumlah calon peserta yang terdaftar sebanyak 980 orang, dengan jumlah peserta yang dapat divaksin sejumlah 972 orang, dan 8 orang sisanya harus mengalami penundaan vaksin karena riwayat kesehatan, tekanan darah tidak sesuai dengan ketentuan 180/80. Perserta yang dapat diberikan vaksin harus memenuhi syarat tekanan darah maksimal 180/80 (Dahlia \& Kurniadi, 2015). Tim PkM Perguruan Tinggi Lepisi memberikan masukan kepada Tim UPT Puskesmas Karawaci untuk menindaklanjuti peserta yang harus mengalami penundaan, bagi yang mengalami penundaan dikarenakan masalah riwayat kesehatan disarankan agar Tim UPT Puskesmas Karawaci untuk memberikan rujukan ke unit kesehatan yang lebih tinggi agar dapat memperoleh penanganan yang lebih lanjut, sedangkan bagi yang memiliki permasalahan tekanan darah disarankan agar memperoleh pendampingan berupa pengecekan kesehatan lebih lanjut dan pemberian obat-obatan pengontrol tekanan darah (Rahman, 2021).

Untuk tanggal 3 Agustus 2021 terdapat 1.000 calon peserta yang terdaftar, yang terdiri dari 976 peserta yang berhasil memperoleh vaksin dan 24 peserta harus mengalami penundaan. Penundaan ini harus dilakukan karena beberapa peserta mengalami permasalahan terkait tekanan darah dan masalah riwayat kesehatan lainnya. Agar peserta yang mengalami penundaan tetap dapat divaksin di periode berikutnya, Tim PkM Perguruan Tinggi Lepisi menyarankan agar UPT Puskesmas Karawaci memberikan pendampingan kesehatan dan obat pengontrol tekanan darah bagi peserta yang mengalami permasalahan tekanan darah, sedangkan bagi yang memiliki masalah riwayat kesehatan disarankan agar UPT Puskesmas Karawaci untuk memberikan rujukan ke unit kesehatan yang lebih tinggi, agar dapat segera ditangani dengan lebih intensif. Pelaksanaan vaksin tanggal 4 Agustus 2021 menunjukkan jumlah calon peserta yang telah mendaftar sebanyak 972 orang, dengan jumlah peserta yang dapat memperoleh vaksin 970 orang, dan 2 orang harus mengalami penundaan karena riwayat kesehatan maupun tekanan darah. Masukan yang Tim PkM Perguruan Tinggi Lepisi berikan kepada Tim UPT Puskesmas Karawaci untuk menindaklanjuti peserta yang harus mengalami penundaan berupa pemberian rujukan ke unit kesehatan yang lebih tinggi agar dapat memperoleh penanganan yang lebih intensif bagi peserta yang memiliki masalah riwayat kesehatan, sedangkan bagi yang memiliki permasalahan tekanan darah disarankan agar memperoleh pendampingan dari UPT Puskesmas Karawaci berupa pengecekan kesehatan lebih lanjut dan pemberian obat-obatan pengontrol tekanan darah. Jumlah calon peserta yang telah mendaftar untuk dilakukan vaksin pada tanggal 5 Agustus 2021 sebanyak 994 orang, yang terdiri dari 988 orang yang berhasil memperoleh vaksin dan 6 orang tidak dapat memperoleh vaksin dan harus mengalami penundaan diakibatkan permasalahan riwayat kesehatan dan tekanan darah.

Untuk menanggulangi beberapa peserta yang harus mengalami penundaan ini, Tim PkM Perguruan Tinggi Lepisi memberikan saran agar peserta yang memiliki riwayat permasalahan kesehatan untuk diberikan rujukan oleh UPT Puskesmas Karawaci ke unit kesehatan lebih tinggi agar dapat segera memperoleh penanganan yang lebih intensif, dan bagi yang bermasalah dengan tekanan darah ini agar diberikan pendampingan kesehatan dari tenaga kesehatan serta pemberian obat-obatan pengontrol tekanan darah (Kristanto \& dkk., 2020). Jumlah keseluruhan calon peserta 
pada pelaksanaan vaksin periode 1 untuk dosis 1 sebanyak 3.946 orang, yang terdiri dari 3.906 peserta yang berhasil divaksin dan 40 peserta yang harus mengalami penundaan akibat permasalahan riwayat kesehatan ataupun tekanan darah.

\section{Pemberian Vaksin dosis 2}

Pelaksanaan dosis 2 dilaksanakan tanggal 16 Agustus 2021. Peserta vaksin dosis 2 adalah semua peserta vaksin yang telah memperoleh dosis 1 . Data peserta vaksin dosis 2 sebagai berikut:

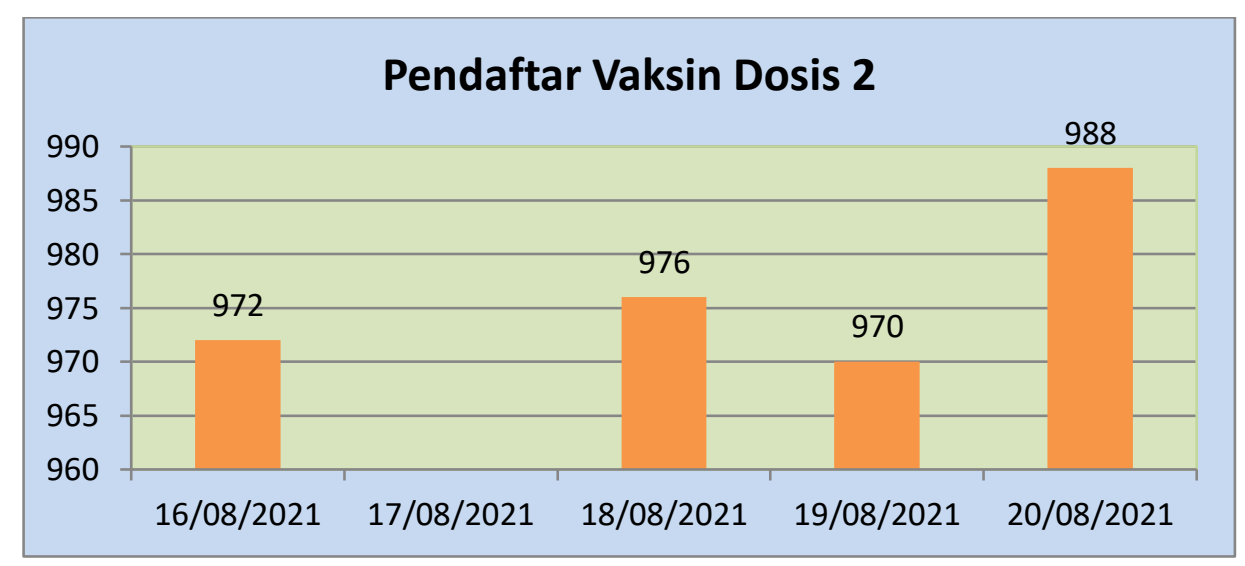

Gambar 9. Grafik data peserta vaksin dosis 2

Jumlah pendaftar vaksin dosis 2 adalah 972 calon peserta untuk pelaksanaan tanggal 16 Agustus 2021. Untuk tanggal 17 Agustus 2021 tidak dilaksanakan kegiatan vaksin dikarenakan pada tanggal tersebut merupakan Hari Peringatan Kemerdekaan Republik Indonesia, walaupun di wilayah/daerah lain masih ada yang melakukan kegiatan vaksin dengan tagline "Gebyar Vaksin 17 Agutus". Untuk tanggal 18 Agustus 2021, jumlah calon peserta yang telah terdaftar sebanyak 976 orang. Pada tanggal 19 Agustus 2021 jumlah calon peserta sebanyak 970 sedangkan pada tanggal 20 Agustus 2021 calon peserta yang telah mendaftar sebanyak 988. Secara keseluruhan jumlah calon peserta pada periode 1 untuk dosis 2 sebanyak 3.906 orang.

Hasil Pelaksanaan vaksinasi dosis 2 pada periode 1 ini dijelaskan pada grafik berikut ini:

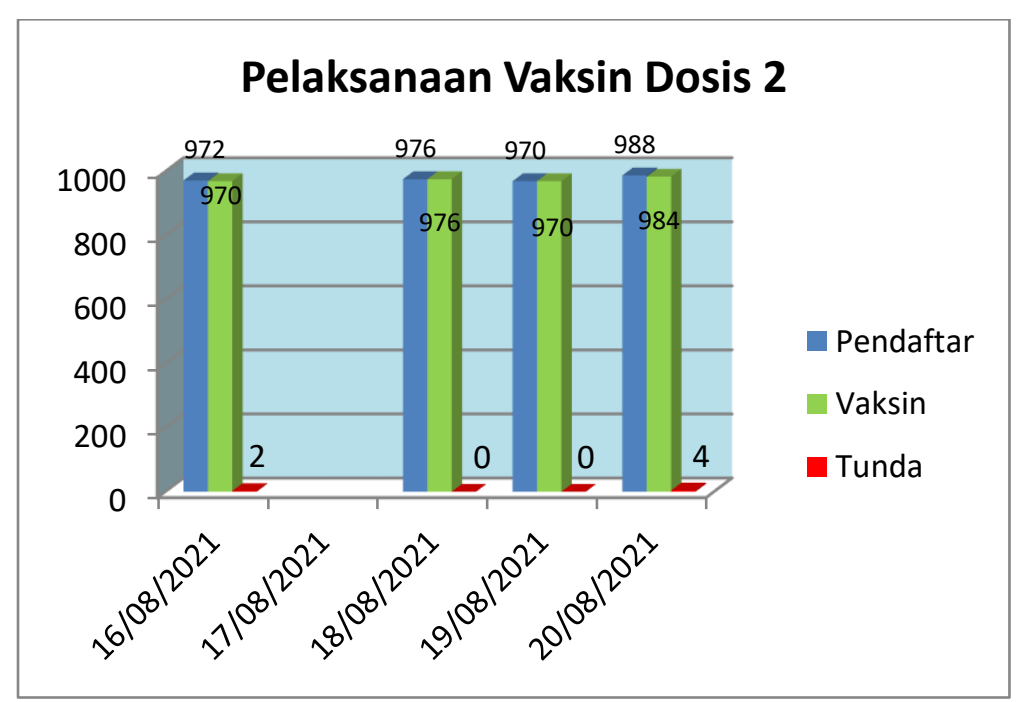

Gambar 10. Grafik hasil pelaksananaan vaksin dosis 2 
Peran Perguruan Tinggi Lepisi dalam Memfasilitasi Pemberantasan Covid-19 di Karawaci Tangerang Banten

Pelaksanaan vaksin dosis 2 dimulai pada tanggal 16 Agustus 2021 dengan jumlah calon peserta sebanyak 972 orang, 970 orang dapat memperoleh vaksin pada hari tersebut, dan 2 orang harus mengalami penundaan yang diakibatkan adanya riwayat masalah kesehatan dan tekanan darah. Untuk menanggulangi permasalahan yang timbul tersebut, maka Tim PkM Perguruan Tinggi Lepisi menyarankan agar peserta yang memiliki riwayat permasalahan kesehatan untuk diberikan rujukan oleh UPT Puskesmas Karawaci ke unit kesehatan lebih tinggi agar dapat segera memperoleh penanganan yang lebih intensif, dan bagi yang bermasalah dengan tekanan darah diri agar diberikan pendampingan kesehatan dari tenaga kesehatan serta pemberian obatobatan pengontrol tekanan darah. Pada tanggal 17 Agustus 2021 kegiatan pelaksanaan vaksin ditiadakan, karena hari tersebut merupakan Hari Peringatan Kemerdekaan, akan tetapi di wilayah lain masih ada kegiatan serupa yang dilakukan dalam rangka "Gebyar Vaksin 17 Agustus".

Tanggal 18 Agustus 2021 pelaksanaan vaksin dosis 2 dilakukan kembali dengan jumlah pendaftar calon peserta sebanyak 976 orang, dan seluruh calon tersebut dapat memperoleh vaksin. Tanggal 19 Agustus 2021 merupakan pelaksanaan vaksin dosis 2 hari ke-3, dengan jumlah pendaftar sebanyak 970 calon peserta, dan seluruh calon peserta tersebut dapat menerima vaksin. Pelaksanaan hari terakhir vaksin dosis 2 dilaksanakan pada tanggal 20 Agustus 2021 dengan jumlah pendaftar sebanyak 988 calon peserta. Dari jumlah tersebut 984 diantaranya telah menerima vaksin pada hari tersebut, selebihnya sebanyak 4 orang calon peserta tidak dapat menerima dikarenakan faktor masalah riwayat kesehatan dan tekanan darah yang tidak sesuai dengan ketentuan yang telah ditetapkan, yaitu 180/80 (Dahlia \& Kurniadi, 2015).

Tim PkM Perguruan Tinggi Lepisi menyarankan agar UPT Puskesmas Karawaci memberikan pendampingan kesehatan dan obat pengontrol tekanan darah bagi peserta yang mengalami permasalahan tekanan darah, sedangkan bagi yang memiliki masalah riwayat kesehatan disarankan agar UPT Puskesmas Karawaci untuk memberikan rujukan ke unit kesehatan yang lebih tinggi, agar dapat segera ditangani dengan lebih intensif. Saran ini dikemukakan Tim PkM Perguruan Tinggi Lepisi, sebagai bentuk hasil observasi kondisi di lapangan. Pelaksanaan vaksin periode 1 untuk dosis 2 telah dilaksanakan sejak tanggal 16 Agustus 2021 dan berakhir pada 20 Agustus 2021. Pada periode ini jumlah calon peserta yang terdaftar sebanyak 3.906 orang, yang terdiri dari 3.900 peserta yang berhasil divaksin dan 6 peserta yang harus mengalami penundaan akibat permasalahan riwayat kesehatan ataupun tekanan darah.

\section{KESIMPULAN}

Pelaksanaan PkM di lingkungan pergururan tinggi Lepisi yang direncanakan sejak tanggal 1 Juli 2021 yang berakhir pada tanggal 31 Agustus 2021 dengan tema memfasilitasi pemberantasan covid-19 di Kecamatan Karawaci Tangerang, merupakan bentuk nyata pengabdian Perguruan Tinggi Lepisi dalam mengabdi kepada masyarakat dan mendukung program pemerintah.

Pelaksanaan vaksin di lingkungan perguruan tinggi dilaksanakan dalam 2 (dua) periode yaitu periode 1 dan periode 2 (periode 2 tidak dibahas dalam artikel ini) baik untuk pelaksanaan vaksin dosis 1 dan dosis 2 . Pendaftar pada periode 1 untuk dosis 1 sebanyak 3946 peserta. Dari jumlah tersebut berhasil menerima vaksin dosis 1 sebanyak 3906 peserta dan 40 peserta harus mengalami penundaan karena alasan kesehatan. 
Pelaksanaan dosis 2 pada periode 1 yang mendaftar sebanyak 3906 peserta(jumlah peserta yang telah mendapat vaksin dosis 1). Dari jumlah tersebut yang berhasil mendapat vaksin dosis 2 sebanyak 3900 peserta dan sebanyak 6 peserta mengalami penundaan karena tidak memenuhi persyaratan kesehatan.

Tim PkM Perguruan Tinggi Lepisi berupaya dan memberikan masukan kepada UPT Puskesmas untuk menindaklanjuti peserta yang mengami penundaan dan pendampingan agar memenuhi persyaratan kesehatan, sehingga semua pendaftar dapat memperoleh vaksin.

Namun di sisi lain, pengabdian kepada masyarakat yang dilaksanakan perguruan tinggi Lepisi memiliki kendala utama yang dihadapi saat pelaksanaan vaksinasi yaitu jumlah dosis yang masih sangat terbatas, tidak mencukupi jumlah pendaftar. Jumlah vaksin yang siap suntik masih terbatas. Pemerintah, dalam hal ini Puskesmas Karawaci telah berusaha untuk mempercepat kedatangan dan kesiapan vaksin untuk segera digunakan.

Terlaksananya pengabdian kepada masyarakat di perguruan tinggi Lepisi dalam memfasilitasi pemberian vaksin covid-19 kepada masyarakat, luaran dari pengabdian kepada masyarakat perguruan tinggi Lepisi ini diharapkan dapat menjadi acuan bagi penulis lain dalam melaksanakan pengabdian kepada masyarakat lanjutan.

\section{UCAPAN TERIMA KASIH}

Dengan selesainya kegiatan PkM Perguruan Tinggi Lepisi yang dimulai tanggal 1 Juli 2021 dan diakhiri pada tanggal 31 Agustus 2021, tim PkM Perguruan Tinggi Lepisi mengucapkan terimakasih atas dukungan moril dan materil kepada semua pihak, khususnya kepada:

1. Ketua Yayasan Widya Anindya Tangerang

2. Pimpinan UPT Puskesmas Kecamatan Karawaci Baru Tangerang dan tim.

3. Ketua STIE Bisma Lepisi

4. Direktur ASM Lepisi Tangerang

5. Camat Kecamatan Karawaci Tangerang

6. Kepala lingkungan kelurahan di wilayah Kecamatan Karawci Tangerang dan Babinsa

7. Tim Gugus Covid Kecamatan Karawaci Tangerang dan Gugus Covid Perguruan Tinggi Lepisi

8. Tim Security Perguruan Tinggi Lepisi.

\section{DAFTAR PUSTAKA}

Amir, H. \& dkk. (2021). Penerapan 3M dalam Mencegah Penularan Covid-19 di Desa Lonjoboko Kabupaten Gowa. Idea Pengabdian Masyarakat, Vol.1, No. 1, 1-4.

Dahlia, D. E. \& Kurniadi, A. (2015). Rancangan Sistem Informasi Pengelolaan Logistik Vaksin Berbasis Web Untuk Mendukung Monitoring Vaksin Di Dinas Kesehatan Kabupaten Kotawaringin Barat Tahun 2015. Semarang: Fakultas Kesehatan Universitas Dian Nuswantoro.

Iskak, \& dkk. (2021). Meningkatkan Kesadaran Masyarakat Tentang Pentingnya Vaksinasi Di Masjid Al - Ikhlas, Jakarta Barat. PADMA: Pengabdian Kepada Masyarakat, Vol.1, No.3, 1-5.

Kristanto, T. \& dkk. (2020). Sosialisasi Pencegahan Penanganan Wabah Covid-19 Terhadap Komunitas Tunarungu Di Kota Surabaya. JURNAL ABDIDAS, 
Peran Perguruan Tinggi Lepisi dalam Memfasilitasi Pemberantasan Covid-19 di Karawaci Tangerang Banten

Community Development Service on Educational and Health Sciences, Vol. 1, No.2, 43-47.

Kusumadewi, A. \& Lestari, A. D. (2020). Gambaran Sistem Pengelolaan Rantai Dingin Vaksin Di Beberapa Puskesmas Kecamatan Di Wilayah Jakarta Timur Tahun 2019. Medical Sains, Vol. 4, No.2, 153-162.

Kurniawan, H. (2021, 3 Agustus). Pemkot Tangerang Tetap Lanjutkan PPKM Level 4 Meski Keterisian RS Covid-19 Terus Turun. Okezone. https:/ / megapolitan.okezone.com/read/2021/08/03/338/2450260/pemkottangerang-tetap-lanjutkan-ppkm-level-4-meski-keterisian-rs-covid-19-terus-turun

Lubabah \& Raynaldo, G. (2021). Menunggu Terobosan Pemerintah Memperluas Jangkauan Vaksinasi ke Pelosok Daerah. Merdeka.com. https://www.merdeka.com/peristiwa/menunggu-terobosan-pemerintahmemperluas-jangkauan-vaksinasi-ke-pelosok-daerah.html.

Lamirin \& dkk. (2021) . Sosialisasi Dan Vaksinasi Covid-19 Kepada Tenaga Pendidik Serta Kependidikan Di Perguruan Buddhis Bodhicitta Medan. Jurnal Pengabdian Kepada Masyarakat Bodhi Dharma vol. 1, No. 1, Agustus 2021.

Mandong, O. T. P. (2019). Sistem Penyimpanan Dan Distribusi Vaksin Di Puskesmas Tarus Tahun 2019 (Doctoral dissertation, Poltekkes Kemenkes Kupang).

Munir, N. W. \& Alam, R. I. (2021).Pencegahan Penularan Covid-19 dengan 3M di Kelurahan Rappokalling Makassar. Idea Pengabdian Masyarakat, Vol. 1, No. 1, 15.

Prayitno, S. A. \& dkk. (2020). Peran Serta Dalam Melaksanakan Protokol Pencegahan Penyebaran Corona Virus Disease (Covid-19) Pada Masyarakat. DedikasiMU (Journal of Community Service) Volume 2, Nomor 3, 1-7.

Portal Resmi Informasi Covid-19 Pemprov. Banten. (2021, 17 Agustus). Kasus Konfirmasi (KK) Covid-19 Provinsi Banten. CoronaCovid19. https: / infocorona.bantenprov.go.id/kasus-konfirmasi

Rahman, I. (2021). Unhas Fasilitasi Vaksinasi Covid-19 Untuk Keluarga Dosen dan Staf Kependidkan. Universitas Hasanuddin. https:/ / unhas.ac.id/v2/article/title/unhas-fasilitasi-vaksinasi-covid-19-untukkeluarga-dosen-dan-staf-kependidikan/

Sardjoko, M. D. S. (2021). Studi Pembelajaran Penanganan COVID-19 di Indonesia. Jakarta: Direktorat Kesehatan dan Gizi Masyarakat Bappenas.

Syamsir, M. R. \& dkk. (2021). Upaya Pencegahan Transmisi COVID-19 melalui Penyuluhan Penggunaan Masker bagi Siswa-Siswi di Desa Tellumpanuae Kecamatan Mallawa. Idea Pengabdian Masyarakat, 1-6.

Ulumuddin, A., Saputra, H. J. \& Listyarini, I. (2020). Pkm Edukasi Pencegahan Penanganan Pertama Covid-19 Di Kelurahan Barusari Kecamatan Semarang Selatan Kota Semarang. In Seminar Nasional Hasil Penelitian dan Pengabdian Kepada Masyarakat (pp. 149-156).

Wilianarti, P. F. \& Wulandari, Y. (2021). Optimalisasi Peran Kader Menggunakan Peer Group Education Dalam Meningkatkan Cakupan Vaksinasi Covid-19. Jurnal Pengabdian Masyarakat Berkemajuan, 1-7.

Zubaedah, I. (2021). Sosialisasi Pentingnya Vaksinasi Covid-19 Untuk Indonesia Sehat Di Perumnas Suradita Cisauk Kabupaten Tangerang Banten. Jakarta: Fakultas Ilmu Sosial Universitas Jayabaya. 
Peran Perguruan Tinggi Lepisi dalam Memfasilitasi Pemberantasan Covid-19 di Karawaci Tangerang Banten

\author{
* Amir Hamzah, SE., Ak., MM (Corresponding Author) \\ ASM Lepisi Tangerang, \\ Jl. KS Tubun 11 Tangerang, Banten, 15112, Indonesia \\ Email: fham.mmh@gmail.com
}

RR Prima Dita Hapsari, SE., Ak., M.Si., CA

STIE Bisma Lepisi Tangerang,

Jl. KS Tubun 11 Tangerang, Banten, 15112, Indonesia

Email: primadita86@gmail.com

Paula Theodora, SE., MM

ASM Lepisi Tangerang,

Jl. KS Tubun 11 Tangerang, Banten, 15112, Indonesia

Email: paula.lepisi@gmail.com

Dahlia Amelia, SE., MM

ASM Lepisi Tangerang

Jl. KS Tubun 11 Tangerang, Banten, 15112, Indonesia

Email: dahliaamelia13@gmail.com

Dasa Rahardjo Soesanto, SS., MM

STIE Bisma Lepisi Tangerang,

Jl. KS Tubun 11 Tangerang, Banten, 15112, Indonesia

Email: dasarahardjo@gmail.com

Ipah Masripah, SE., MM

ASM Lepisi Tangerang

Jl. KS Tubun 11 Tangerang, Banten, 15112, Indonesia

Email: ipahmasrifa@yahoo.com

Hesti Umiyati, SE., MM

ASM Lepisi Tangerang

Jl. KS Tubun 11 Tangerang, Banten, 15112, Indonesia

Email: hestiumiyati@gmail.com

Suhadarliyah, SS., SE., MM

STIE Bisma Lepisi Tangerang,

Jl. KS Tubun 11 Tangerang, Banten, 15112, Indonesia

Email: suhadarliyah.liyah2909@gmail.com 